\title{
Produksi dan Optimasi Biosurfaktan dari Bakteri Halofilik Chromohalobacter japonicus BK-AB18
}

\author{
Production and Optimization of Biosurfactant from Halophilic Bacteria Chromohalobacter \\ japonicus $B K-A B 18$
}

\author{
Cut Yuliana $^{1^{*)}}$, Rukman Hertadi ${ }^{2)}$, Deana Wahyuningrum²) \\ ${ }^{1)}$ STIKes Assyifa Aceh, Prodi Farmasi \\ ${ }^{2}$ Institut Teknologi Bandung, Fakultas MIPA, Prodi Kimia \\ *Email: cutyuliana89@gmailcom
}

Received: 19/11/19; Revised: 17/12/19; Accepted: 17/12/19

\begin{abstract}
Abstrak
Perkembangan teknologi bioproses telah mendorong pendekatan ke arah produk surfaktan biologi (biosurfaktan) yang ramah lingkungan. Penelitian ini difokuskan pada optimasi produksi biosurfaktan dengan menggunakan variasi sumber karbon dan nitrogen. Tahap awal penelitian ini dilakukan dengan menguji potensi bakteri Chromohalobacter japonicus BK-AB18 penghasil biosurfaktan dengan menggunakan metode uji hemolisis dimana hasil menunjukkan aktivitas hemolisis yang tinggi dengan ukuran zona bening $3 \mathrm{~cm}$ pada media agar darah. Selanjutnya dilakukan produksi pada medium optimal dengan menambahkan $2 \%$ variasi sumber karbon terdiri dari minyak zaitun, minyak jagung, minyak kelapa sawit, minyak kacang kedelai dan minyak bunga matahari serta $0,3 \%$ variasi nitrogen terdiri dari urea, $\mathrm{NaNO}_{3}, \mathrm{NH}_{4} \mathrm{Cl}, \mathrm{NH}_{2}(\mathrm{SO})_{4}$ and $\mathrm{KNO}_{3}$. Hasil penelitian menunjukkan produksi biosurfaktan dari Chromohalobacter japonicus BK-AB18 meningkat secara signifikan dengan menggunakan minyak zaitun sebagai sumber karbon dan urea sebagai sumber nitrogen dengan hasil penyebaran minyak $4,8 \mathrm{~cm}$ serta aktivitas biosurfaktan dengan nilai tegangan permukaan sebesar 34 dyne/cm, dan hasil uji emulsifikasi sebesar $76 \%$.
\end{abstract}

Kata kunci: Bakteri Halofilik, Biosurfaktan, Chromohalobacter japonicus, Medium optimal

\begin{abstract}
The development of bioprocess technology has pushed an approachtowards environmentally friendly biological surfactant (biosurfactant) product. This research is focused on optimizing biosurfactant production by using variations in carbon and nitrogen sources. The first stage of this research was conducted by testing the potential of biosurfactant producing Chromohalobacter japonicus BK-AB18 using a hemolysis test method where the results showed high hemolysis activity with $3 \mathrm{~cm}$ clear zone on blood agar media. Furthermore, production an optimal medium by adding $2 \%$ variation in carbon sources as olive oil, corn oil, palm oil, soybean oil, sunflower oil and $0.3 \%$ variation of nitrogen source as urea, $\mathrm{NaNO}_{3}, \mathrm{NH}_{4} \mathrm{Cl}, \mathrm{NH}_{2}(\mathrm{SO})_{4}$ and $\mathrm{KNO}_{3}$. The result showed that biosurfactant production from Chromohalobacter japonicas BK-AB18 increased significantly by using olive oil as carbon source and urea as a nitrogen source with the results $4.8 \mathrm{~cm}$ oil spread and biosurfactant activity with a surface tension value of 34 dyne/cm, and the results of an emulsification test of $76 \%$.
\end{abstract}

Keywords: Biosurfactant, Chromohalobacter japonicus, Halophilic Bacteria, Optimal Medium 


\section{PENDAHULUAN}

Biosurfaktan merupakan surfaktan yang ramah lingkungan yang terdiri dari molekul amphipatic atau amphiphilic yang mengandung gugus hidrofobik dan lipofilik dan disintesis secara ekstraseluler oleh mikroorganisme. Biosurfaktan banyak diminati karena sifatnya yang ramah lingkungan dengan biodegradable (dapat terdegradasi secara alami) dan tidak toksik (Mulligan, 2005)

Mikroorganisme halofilik adalah mikroorganisme yang dapat hidup pada kondisi lingkungan ekstrem dengan kadar garam tinggi. Mikroorganisme yang umumnya hidup pada lingkungan ini yaitu bakteri halofilik moderat dan arkea (archaea) halofilik ekstrem (Kushner 1985 dalam Ventosa $d k k$., 1998) halofilik moderat adalah kelompok mikroorganisme yang tumbuh optimum pada kadar $\mathrm{NaCl} 5-25 \%$. Bakteri halofilik moderat memiliki banyak potensi, yaitu dalam fermentasi makanan, penghasil senyawa osmoprotektan, enzim hidrolitik, polimer, dan degradasi senyawa toksik (Ventosa $d k k .$, 1998). Bakteri halofilik penghasil biosurfaktan sebelumnya telah diteliti oleh (Donio $d k k$., 2013, Sarafin $d k k$., 2014, Henriet $d k k$., 2014 dan Kumar $d k k$., 2014).

Penelitian ini menggunakan bakteri halofilik isolat lokal Chromohalobacter japonicus BK-AB18 yang diperoleh dari koleksi laboratorium Biokimia ITB yang telah diisolasi dan dianalisis 16 sRNA oleh Asy'ari $d k k$. (2014) yang berasal dari kawah lumpur bleduk kuwu, purwodadi, Jawa Tengah. Selanjutnya penyebutan bakteri pada artikel ini adalah $C$. japonicus.

Produksi biosurfaktan dari mikroba tergantung dari jenis mikroorganisme dan kondisi pertumbuhan seperti sumber karbon, sumber nitrogen, $\mathrm{pH}$ dan temperatur.
(Kosaric $d k k .$, 1987). Oleh karena itu, pada penelitian ini biosurfaktan diproduksi dari bakteri halofilik isolat lokal C. japonius BKAB18 dengan menggunakan variasi sumber karbon dan nitrogen agar memperoleh biosurfaktan yang optimal.

\section{METODE PENELITIAN}

Alat

Alat-alat yang digunakan pada penelitian ini meliputi alat gelas terdiri dari gelas kimia, tabung reaksi, cawan petri, corong, erlenmeyer, gelas ukur, batang pengaduk, lampu spiritus dan pipet tetes. Alat non gelas terdiri dari spatula, jarum ose, pengaduk magnetik, autoklaf, penangas air, vortex, shaker incubator, freeze dryer, tip eppendrofe ukuran 1-10 $\mu \mathrm{L}, 100-200 \mu \mathrm{L}$, 500-1000 $\mu \mathrm{L}, \quad \mathrm{pH}$ meter, inkubator, sentrifuga dan timbangan elektrik serta tensiometer Du Nouy alat untuk mengukur aktivitas biosurfaktan

\section{Bahan}

Bahan-bahan yang digunakan dalam penelitian ini meliputi bakteri isolat lokal $C$. japonicus galur BK-AB18 yang diperoleh dari koleksi laboratorium Biokimia ITB. Bahan yang digunakan untuk medium pertumbuhan bakteri yaitu medium NB dan NA terdiri dari pepton, bakto agar, ekstrak daging, ekstrak ragi yang diperoleh dari Difco sedangkan untuk medium (CY) terdiri dari $\mathrm{NaCl}, \quad \mathrm{MgSO}_{4} .7 \mathrm{H}_{2} \mathrm{O}, \quad \mathrm{CaCl}_{2} .2 \mathrm{H}_{2} \mathrm{O}$, $\mathrm{FeSO}_{4} .7 \mathrm{H}_{2} \mathrm{O}, \mathrm{K}_{2} \mathrm{HPO}_{4}, \mathrm{KH}_{2} \mathrm{PO}_{4}$, Gliserol, $\mathrm{Na}_{2} \mathrm{HPO}_{4}, \quad \mathrm{Na}_{2} \mathrm{HPO}_{4}$ yang semua bahan berasal dari Merck. Variasi sumber karbon yang digunakan untuk medium optimasi produksi biosurfaktan adalah minyak zaitun, minyak sawit, minyak bunga matahari, minyak jagung dan minyak kacang kedelai. Variasi sumber nitrogen yang digunakan untuk medium optimasi produksi 
biosurfaktan adalah Urea, $\mathrm{NH}_{4} \mathrm{Cl}, \mathrm{NaNO}_{3}$, $\left(\mathrm{NH}_{4}\right)_{2} \mathrm{SO}_{4}$ dan $\mathrm{KNO}_{3}$ (semua bahan berasal dari Merck).

\section{Pembuatan Media padat Nutrient Agar} (NA)

Media NA digunakan untuk menumbuhkan bakteri-bakteri uji. Komposisi media NA dalam (w/v) adalah $1 \%$ pepton, $10 \% \mathrm{NaCl}, 0,5 \%$ ekstrak daging sapi dan 2\% agar. Media dilarutkan hingga homogen dengan menggunakan pengaduk magnetik. Kemudian $\mathrm{pH}$ diatur hingga $\mathrm{pH} 7$ kemudian disterilkan menggunakan autoklaf pada $121{ }^{\circ} \mathrm{C}$ selama 15 menit.

\section{Pembuatan Media cair Nutrient Broth (NB)}

Media NB digunakan untuk menumbuhkan bakteri uji. Komposisi media NB sama seperti media NA hanya saja tanpa menggunakan agar. Selanjutnya, media dilarutkan hingga homogen dengan menggunakan pengaduk magnetik kemudian $\mathrm{pH}$ diatur hingga $\mathrm{pH} 7$ kemudian disterilkan menggunakan autoklaf pada $121{ }^{\circ} \mathrm{C}$ selama 15 menit.

\section{Pembuatan Media Minimal CY}

Media Minimal $C Y$ digunakan untuk produksi biosurfaktan. Komposisi media dalam (w/v) adalah $0,3 \%$ Urea, $0,05 \%$ $\mathrm{KH}_{2} \mathrm{PO}_{4}, 0,1 \% \quad \mathrm{~K}_{2} \mathrm{HPO}_{4}, 5 \% \mathrm{NaCl}, 0,05 \%$ $\mathrm{MgSO}_{4} .7 \mathrm{H}_{2} \mathrm{O}, 0,001 \% \mathrm{CaCl}_{2} .2 \mathrm{H}_{2} \mathrm{O}, 0,001 \%$ FeSO $4.7 \mathrm{H}_{2} \mathrm{O}, 0,1 \%$ ekstrak ragi dan $2 \%$ $(\mathrm{v} / \mathrm{v})$ sumber karbon selanjutnya diatur hingga $\mathrm{pH}$ 7. Semua pengujian diulang sebanyak tiga kali. Kemudian media disterilkan menggunakan autoklaf pada suhu $121{ }^{\circ} \mathrm{C}$ selama 15 menit. Selanjutnya kultur diinokulasi sebanyak $2 \%$ (v/v) dan dikocok menggunakan shaker incubator dengan kecepatan $150 \mathrm{rpm}$ pada $37^{\circ} \mathrm{C}$ selama 4 hari

\section{Uji Potensi Bakteri Penghasil Biosurfaktan}

Metode ini digunakan untuk mendeteksi bakteri yang berpotensi sebagai penghasil biosurfaktan. Medium yang digunakan dalam (w/v) adalah $1 \%$ pepton, $3 \%$ ekstrak ragi, $5 \% \mathrm{NaCl}, 2 \%$ agar dan $5 \%$ (v/v) darah tikus. Media dilarutkan hingga homogen dengan menggunakan pengaduk magnetik kemudian diatur hingga $\mathrm{pH} 7$ dan disterilkan menggunakan autoklaf pada $121^{\circ} \mathrm{C}$ selama 15 menit. Selanjutnya, sebanyak $30 \mu \mathrm{L}$ supernatan diteteskan di atas medium dan diinkubasi pada $37{ }^{\circ} \mathrm{C}$ selama 24-48 jam dan diamati perubahan yang terjadi. Adanya zona bening pada medium menunjukkan hasil positif bahwa bekteri tersebut berpotensi sebagai penghasil biosurfaktan (Desai \& Banat, 1997 dan Ibrahim, 2018).

\section{Prekultur dan Inokulasi ke Media Kultur}

Sebanyak satu ose isolat bakteri penghasil biosurfaktan diinokulasikan ke dalam media NB steril sebanyak $5 \mathrm{~mL}$ sebagai prekultur yang diinkubasi selama 12 jam menggunakan shaker incubator pada 37 ${ }^{\circ} \mathrm{C}$. Kemudian sebanyak $2 \%$ prekultur dimasukkan ke dalam $100 \mathrm{~mL}$ media MM CY steril untuk kultur dan diinkubasi menggunakan shaker incubator selama 4 hari pada $37^{\circ} \mathrm{C}$.

\section{Pembuatan Kurva Pertumbuhan}

Sebanyak satu ose isolat bakteri dipindahkan secara aseptik ke media optimasi steril dan diinkubasi menggunakan shaker incubator pada $37^{\circ} \mathrm{C}$. Selanjutnya, diukur Optical Density (OD) pada $\lambda 600 \mathrm{~nm}$ dilakukan terhadap masing-masing kultur setiap 1 jam hingga diperoleh nilai OD yang stasioner dengan menggunakan blangko berupa media steril. Selanjutnya, kurva 
pertumbuhan dibuat dengan menghubungkan nilai absorban kultur terhadap waktu inkubasi.

\section{Pengaruh Media Pertumbuhan pada} Produksi Biosurfaktan

Optimasi media dilakukan dalam serangkaian percobaan mengubah satu variabel pada satu waktu serta menjaga faktor-faktor lain tetap pada saat kondisi yang spesifik. Dua faktor yang dipilih bertujuan untuk memperoleh produktivitas yang lebih tinggi dari biosurfaktan tersebut yaitu Sumber karbon (C) dan sumber nitrogen (N). Sumber karbon yang digunakan adalah minyak zaitun, minyak sawit, minyak bunga matahari, minyak jagung, minyak kacang kedelai pada konsentrasi $2 \%(\mathrm{v} / \mathrm{v})$, dengan urea sebagai sumber nitrogen dibuat tetap untuk evaluasi yang paling sesuai sebagai sumber nitrogen pada produksi biosurfaktan digunakan amonium sulfat, amonium klorida, kalium nitrat dan sodium nitrat pada konsentrasi $0.3 \%$ (w/v) dengan karbon optimal sebagai sumbernya (Abouseoud $d k k ., 2008$ )

\section{Uji Aktivitas Produksi Biosurfaktan}

\section{a. Pengukuran Tegangan Permukaan (tensiometer Du Nouy)}

Nilai tegangan permukaan supernatan kultur bakteri diukur menggunakan alat tensiometer Du Nouy. Sebanyak $20 \mathrm{~mL}$ supernatan dimasukkan ke dalam gelas kimia yang dibersihkan dari lemak dengan menggunakan alkhohol $70 \%$, selanjutnya dilakukan pengukuran tegangan permukaan supernatan. Penurunan nilai tegangan permukaan sebesar lebih dari 10 dyne/cm menunjukkan bahwa bakteri tersebut berpotensi menghasilkan biosurfaktan (Desai \& Banat, 1997).

\section{b. Uji Penyebaran Minyak (Oil spreading test) \\ Cawan petri (diameter $14 \mathrm{~cm}$ ) yang} telah berisi $40 \mathrm{~mL}$ air suling ditambahkan ditambahkan $100 \mathrm{~mL}$ minyak ke permukaan air. Selanjutnya, $10 \mu \mathrm{L}$ supernatan dari media minimal CY diteteskan di permukaan minyak mentah. Diamkan selama 30 detik selanjutnya diukur diameter zona yang terbentuk pada permukaan minyak diukur dan dibandingkan dengan $10 \mu \mathrm{L}$ air suling sebagai kontrol negatif (Desai \& Banat, 1997; Morikawa dkk., 2000).

\section{c. Uji Emulsifikasi}

Uji emulsifikasi dilakukan untuk mengetahui kemampuan biosurfaktan dalam mengemulsi lapisan lemak. Dalam penelitian ini digunakan minyak sebagai substrat lemak yang akan diemulsi. Perbandingan antara minyak dan kultur cair adalah 2: 2. Tabung reaksi yang berisi $2 \mathrm{~mL}$ minyak ditambahkan $2 \mathrm{~mL}$ supernatan dan divorteks dengan kecepatan tinggi selama 2 menit. Selanjutnya, campuran didiamkan selama 24 jam untuk melihat kestabilan emulsi. Indeks emulsifikasi ditentukan dengan menggunakan persamaan berikut: (Asfora $d k k .$, 2006).

IE $24=\frac{\text { Tinggi Lapisan Emulsi }}{\text { Tinggi lapisan minyak }+ \text { lapisan emulsi }} \times 100 \%$

\section{HASIL DAN PEMBAHASAN \\ Kultivasi Bakteri}

Pada penelitian ini digunakan bakteri halofilik isolat lokal C. japonicus berasal dari Bledug Kuwu. Kultivasi bakteri ini dilakukan dalam 2 medium yaitu medium padat $N A$ dapat dilihat pada Gambar 1.A dan medium cair $N B$ dapat dilihat pada Gambar 1.B. Isolat yang telah dikultivasi disimpan sebagai stok media padat pada suhu $37^{\circ} \mathrm{C}$ untuk digunakan pada penelitian selanjutnya. 


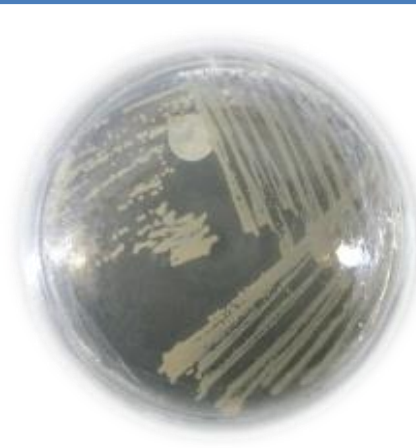

(A)

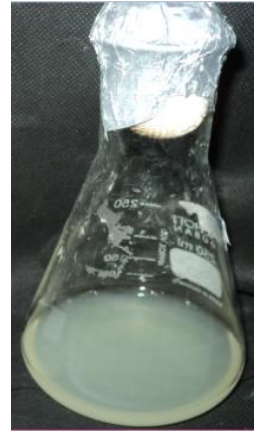

(B)
Gambar 1. (A) Kultivasi dalam media padat $N A$, (B) Kultivasi dalam media cair $N B$

\section{Potensi Bakteri Penghasil Biosurfaktan}

Bakteri penghasil biosurfaktan dapat dilihat dengan menguji potensi bakteri tersebut menggunakan metode uji hemolisis. Suatu bakteri dikatakan positif menghasilkan biosurfaktan jika bakteri tersebut dapat melisis darah dengan terbentuknya zona bening (Ibrahim, 2018). Berdasarkan hasil uji hemolisis yang telah dilakukan $C$. japonicus dapat melisis darah yang dapat dilihat pada Gambar 2. Darah yang digunakan dalam penelitian ini yaitu darah tikus. Ukuran zona bening yang dihasilkan dari $C$. japonicus sebesar $3 \mathrm{~cm}$ sedangkan tipe hemolisis yang dihasilkan yaitu tipe $\beta$ hemolisis yang merupakan lisis lengkap sel darah merah dan hemoglobin (Sharma, \& Gupta, 2014).

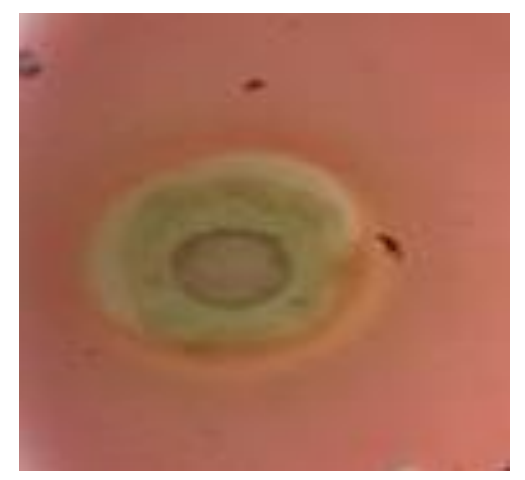

Gambar 2. Aktivitas hemolitik bakteri

C. japonicus penghasil biosurfaktan

\section{Kurva Pertumbuhan}

Setiap bakteri mempunyai media yang spesifik untuk tumbuh. Bakteri akan mengalami tahap kehidupan mulai dari fase pertumbuhan sampai pada fase kematian. Kurva pertumbuhan bakteri ini terdiri dari empat fase yaitu fase lambat atau awal, fase eksponensial fase stasioner dan fase kematian (Barragan $d k k ., 2016)$.

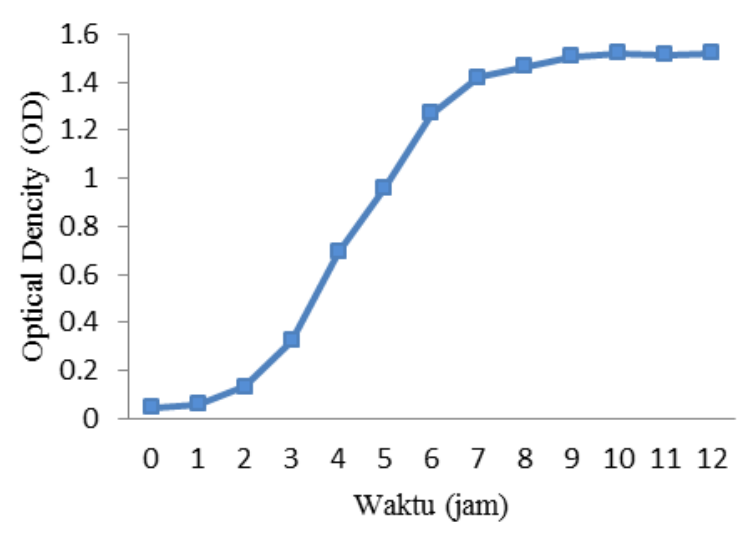

Gambar 3. Kurva Pertumbuhan pada media NB

Berdasarkan kurva pertumbuhan yang dapat dilihat pada Gambar 3, 1 jam pertama pemindahan dari kultur ke dalam media merupakan fase lambat (lag phase), yaitu fase waktu yang dibutuhkan oleh suatu mikroorganisme untuk menyesuaikan diri dengan media yang ada sehingga penambahan jumlah sel lambat dan tidak tampak. Pada saat rentang usia inokulum 2-8 jam terjadi fase logaritma atau fase eksponensial. Pada fase ini mikroorganisme akan membelah diri dengan cepat dan terjadi peningkatan pertumbuhan jumlah sel secara signifikan.

Sedangkan pada waktu 9-11 jam terjadi fase stasioner yaitu terjadi kecepatan pertumbuhan yang konstan atau stabil, tetapi jumlah sel yang tinggi terdapat pada jam ke 10. Selanjutnya pada saat 12 jam menunjukkan fase kematian yaitu ketika mikroorganisme tidak dapat tumbuh lagi bila dipindahkan ke media produksi yang baru. 
Pada penelitian ini usia inokulum yang dipilih untuk menginokulasikan $C$. japonicus dalam media fermentasi adalah 10 jam yang merupakan waktu tumbuh yang optimal pada bakteri tersebut dengan nilai OD (Optical Dencity) sebesar 1,425. Hasil kurva pertumbuhan untuk setiap bakteri berbeda-beda dalam beberapa penelitian (Astuti $d k k ., 2019$; Balan $d k k ., 2017$; dan ElSheshtawy $d k k ., 2015$ )

\section{Optimasi Media Produksi}

Produksi biosurfaktan sangat dipengaruhi oleh medium pertumbuhan yang digunakan. Selain medium minimal produksi, diperlukan juga sumber karbon dan nitrogen tambahan pada medium tersebut. Biosurfaktan yang memiliki karakteristik terbaik yaitu mempunyai nilai kepadatan sel yang tinggi dan aktivitas biosurfaktan yang tinggi salah satunya dengan cara menguji penyebaran minyak (Oil Spreading Test)

Pada penelitian ini sebanyak 2\% prekultur dari medium NB dimasukkan kedalam $100 \mathrm{~mL}$ medium produksi menggunakan media MM CY steril dengan penambahan variasi sumber karbon dan sumber nitrogen untuk kultur dan selanjutnya diinkubasi menggunakan shaker incubator selama 4 hari pada $37^{\circ} \mathrm{C}$. Variasi sumber karbon yang digunakan terdiri dari minyak zaitun, minyak jagung, minyak kelapa sawit, minyak kacang kedelai dan minyak bunga matahari sedangkan untuk variasi sumber nitrogen digunakan urea, natrium nitrat, amonium sulfat, amonium klorida dan kalium nitrat.

Berdasarkan grafik pada Gambar 4 terlihat bahwa $C$. japonicus minyak kacang kedelai memiliki kepadatan sel tertinggi dengan lama waktu tumbuh 3 hari. Hal ini menunjukkan bahwa sumber karbon mempengaruhi pertumbuhan bakteri dalam produksi biosurfaktan.

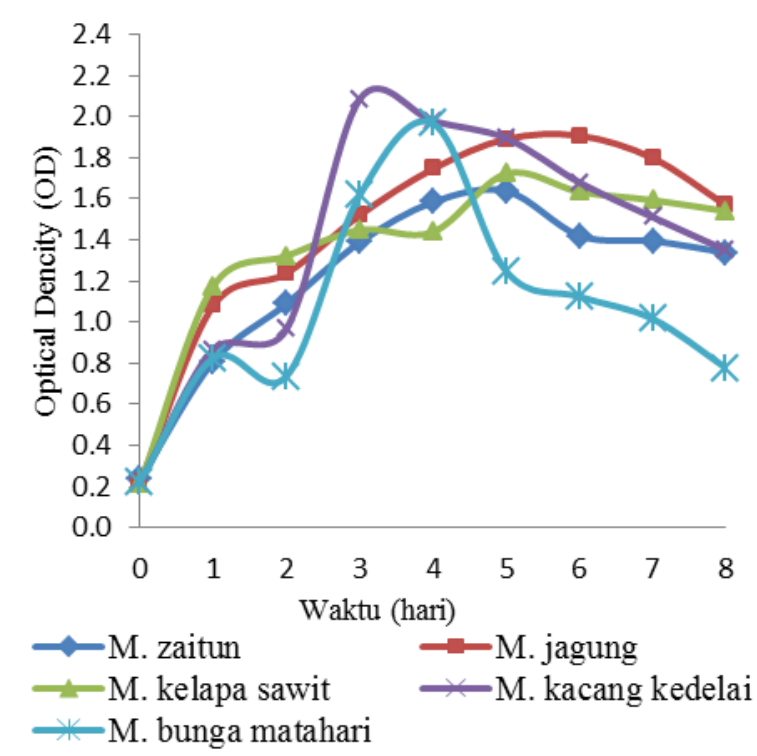

Gambar 4. Kurva pertumbuhan kepadatan sel bakteri $C$. japonicus dengan variasi sumber karbon

Biosurfaktan yang memiliki karakteristik yang baik juga dilihat dari aktivitas biosurfaktannya dengan menggunakan uji penyebaran minyak. Data hasil pengukuran dapat dilihat pada Gambar 5 .

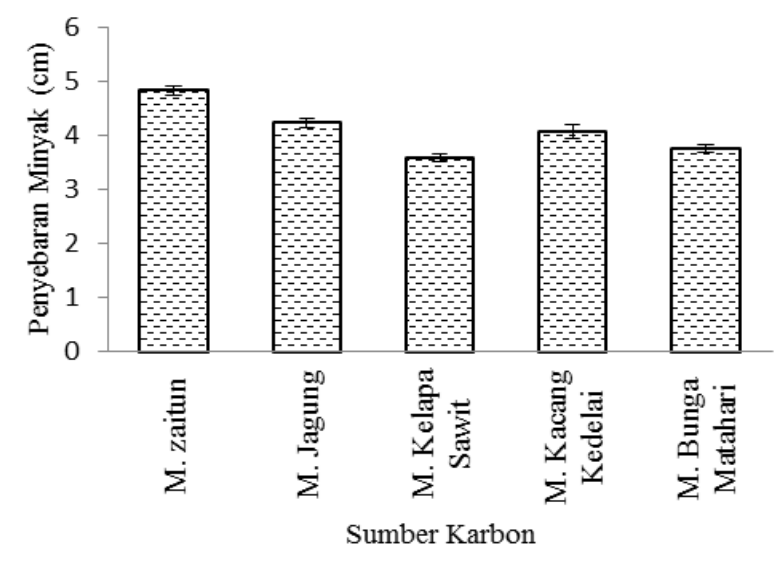

Gambar 5. Grafik aktivitas biosurfaktan pada uji penyebaran minyak dengan variasi sumber karbon

Berdasarkan hasil uji penyebaran minyak terlihat bahwa sumber karbon terbaik untuk produksi biosurfaktan $C$. japonicus yaitu menggunakan minyak zaitun 
dengan aktivitas penyebaran minyak $4,8 \mathrm{~cm}$. Pada beberapa penelitian sumber karbon minyak zaitun juga dapat meningkatkan produksi biosurfaktan (Rahayu, 2015 dan Janaki dkk., 2015). Selanjutnya, sumber karbon terbaik dari bakteri tersebut digunakan untuk menentukan sumber nitrogen terbaik dengan sumber karbon dibuat tetap sedangkan sumber nitrogen dibuat bervariasi.

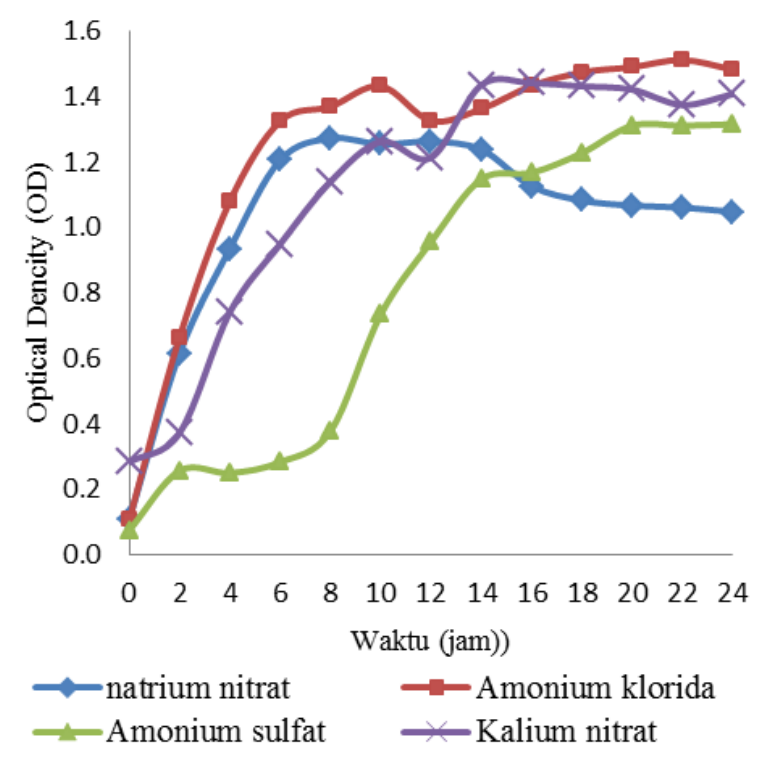

Gambar 6. Kurva pertumbuhan kepadatan sel bakteri $C$. japonicus dengan variasi sumber nitrogen

Berdasarkan grafik pada Gambar 6, dapat diketahui bahwa $C$. japonicus memiliki tingkat kepadatan sel yang tinggi jika menggunakan sumber nitrogen amonium klorida. Sumber nitrogen amonium klorida menyebabkan pertumbuhan sel semakin cepat jika dibandingkan dengan urea sebagai sumber nitrogennya dengan lama waktu tumbuh untuk bakteri tersebut adalah 22 jam. Hal ini menunjukkan bahwa sumber nitrogen dari variasi tersebut dapat mempercepat waktu tumbuh. Biosurfaktan dengan variasi sumber nitrogen selanjutnya diuji aktivitas biosurfaktannya dengan menggunakan uji penyebaran minyak.

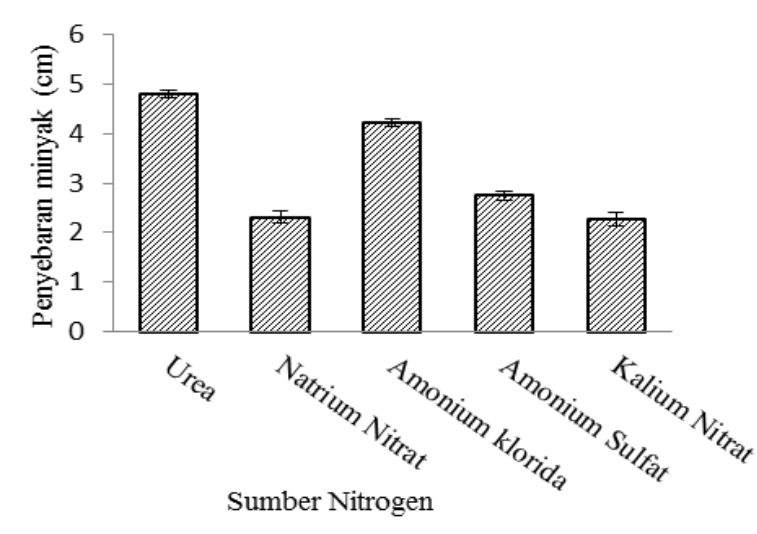

Gambar 7. Grafik aktivitas biosurfaktan pada uji penyebaran minyak dengan variasi sumber nitrogen

Berdasarkan grafik pada Gambar 7 terlihat bahwa sumber nitrogen terbaik untuk produksi biosurfaktan $C$. japonicus yaitu menggunakan urea dengan aktivitas penyebaran minyak sebesar $4,8 \mathrm{~cm}$. Pada beberapa penelitian sumber nitrogen urea juga dapat meningkatkan produksi biosurfaktan (Makkar \& Cameotra, 1997 dan Suganthi, 2013)

Hasil sumber karbon dan nitrogen terbaik selanjutnya diproduksi dalam medium optimal yaitu menggunakan minyak zaitun dan urea.

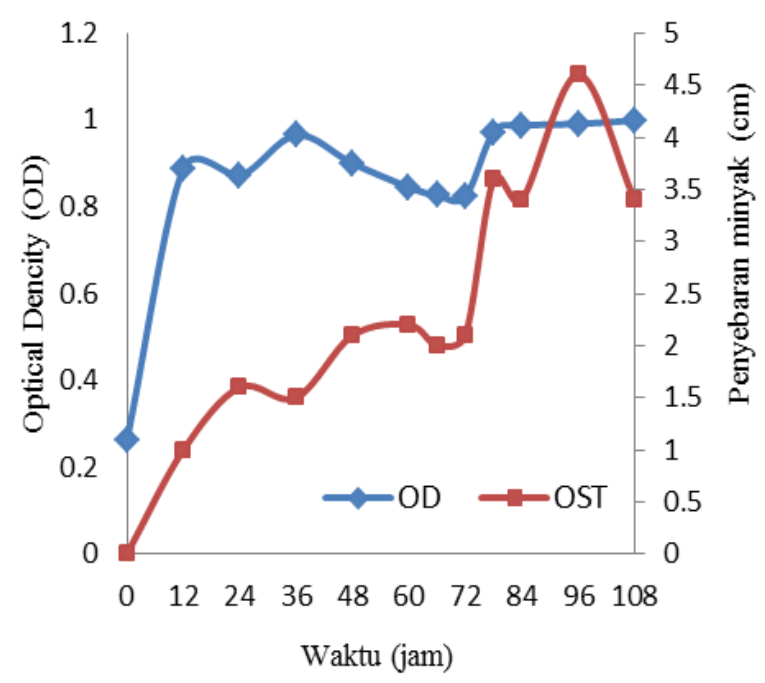

Gambar 8. Kurva pertumbuhan produksi biosurfaktan dari C. japonicus 
Grafik pada Gambar 8 merupakan hasil produksi biosurfaktan dalam media optimasi menggunakan sumber karbon minyak zaitun dan sumber nitrogen urea. Berdasarkan hasil tersebut dapat dilihat bahwa aktivitas produksi biosurfaktan dari $C$. japonicus dihasikan dalam waktu 96 jam dengan nilai penyebaran minyaknya $4,7 \mathrm{~cm}$.

\section{Aktivitas Produksi Biosurfaktan}

Biosurfaktan hasil produksi dalam media optimal selanjutnya diuji aktivitasnya dengan cara menghitung tegangan permukaan, penyebaran minyak, serta uji emulsifikasi. Nilai tegangan permukaan $C$. japonicus sebesar 34 dyne/cm, hasil penyebaran minyak $4,8 \mathrm{~cm}$ dan hasil uji emulsifikasi sebesar $76 \%$.

\section{KESIMPULAN}

Berdasarkan hasil penelitian yang telah dilakukan maka dapat disimpulkan bahwa bakteri halofilik isolat lokal $C$. japonicus $\mathrm{BK}-\mathrm{AB} 18$ berpotensi sebagai penghasil biosurfaktan ditunjukkan dengan adanya aktivitas hemolisis yang tinggi $3 \mathrm{~cm}$ yang ditumbuhkan pada media agar darah.

Produksi biosurfaktan $C$. japonicus naik secara signifikan menggunakan sumber karbon minyak zaitun dan urea sebagai sumber nitrogen dengan hasil penyebaran minyak $4,8 \mathrm{~cm}$, nilai tegangan permukaan sebesar 34 dyne/cm dan uji emulsifikasi sebesar $76 \%$.

\section{DAFTAR RUJUKAN}

Abouseoud, M., Maachi, R., Amrane, A., Boudergua, S., \& Nabi, A. (2008). Evaluation of different carbon and nitrogen sources in production of biosurfactant by Pseudomonas fluorescens. Desalination, 223(1-3), 143-151.
Asfora, S. L., Moura de Luna, J., \& de Campos-Takaki, G. M. (2006). Production and stability studies of the bioemulsifier obtained from a new strain of Candida glabrata UCP 1002. Electronic Journal of Biotechnology, 9(4), 0-0.

Astuti, D. I., Purwasena, I. A., Putri, R. E., Amaniyah, M., \& Sugai, Y. (2019). Screening and characterization of biosurfactant produced by Pseudoxanthomonas sp. G3 and its applicability for enhanced oil recovery. Journal of Petroleum Exploration and Production Technology, 1-11.

Asy'ari, M., Parwata, I. P., Aditiawati, P., Akhmaloka, A., \& Hertadi, R. (2014). Isolation and identification of halostable lipase producing bacteria from the Bledug Kuwu mud crater located at Purwodadi-Grobogan, Central Java, Indonesia. J. Pure Appl. Microbiol, 8(5), 3387-3396.

Balan, S. S., Kumar, C. G., \& Jayalakshmi, S. (2017). Aneurinifactin, a new lipopeptide biosurfactant produced by a marine Aneurinibacillus aneurinilyticus SBP-11 isolated from Gulf of Mannar: purification, characterization and its biological evaluation. Microbiological research, 194, 1-9.

Barragan, L. A. P, Figueroa, J. J. B., Duran, R. L. V., Gonzalez, C. N. A., Hennings, C. (2016). Biotransformation of Agricultural Waste and By-Products, 189-217, https://doi.org/10.1016/B978-0-12803622-8.00007-0

Desai, J. D., \& Banat, I. M. (1997). Microbial production of surfactants and their commercial potential. Microbiol. Mol. Biol. Rev., 61(1), 47-64. 
Donio, M. B. S., Ronica, F. A., Viji, V. T., Velmurugan, S., Jenifer, J. S. C. A., Michaelbabu, M., ... \& Citarasu, T. (2013). Halomonas sp. BS4, A biosurfactant producing halophilic bacterium isolated from solar salt works in India and their biomedical importance. SpringerPlus, 2(1), 149.

El-Sheshtawy, H. S., Aiad, I., Osman, M. E., Abo-ELnasr, A. A., \& Kobisy, A. S. (2015). Production of biosurfactant from Bacillus licheniformis for microbial enhanced oil recovery and inhibition the growth of sulfate reducing bacteria. Egyptian Journal of Petroleum, 24(2), 155-162.

Henriet, O., Fourmentin, J., Delincé, B., \& Mahillon, J. (2014). Exploring the diversity of extremely halophilic archaea in food-grade salts. International journal of food microbiology, 191, 36-44.

Ibrahim, H. M. (2018). Characterization of biosurfactants produced by novel strains of Ochrobactrum anthropi HM1 and Citrobacter freundii HM-2 from used engine oil-contaminated soil. Egyptian Journal of Petroleum, 27(1), 21-29.

Janaki, S., Thenmozhi, S., \& Muthumari, R. (2015). A study on Hydrocarbon Degradation by Biosurfactant Producing Bacillus cereus in Oil Contaminated Soil Samples. Int. J. Life. Sci. Scienti. Res, 2(4).

Kosaric, N., Cairns, W. L., Gray, N. C. C. (1987). Biosurfactants and Biotechnology. USA: Newyork and Bassel, Maecell Dekker, INC.

Kumar, C. G., Sujitha, P., Mamidyala, S. K., Usharani, P., Das, B., \& Reddy, C. R. (2014). Ochrosin, a new biosurfactant produced by halophilic Ochrobactrum sp. strain BS-206 (MTCC 5720): purification, characterization and its biological evaluation. Process Biochemistry, 49(10), 1708-1717.

Makkar, R. S., \& Cameotra, S. S. (1997). Biosurfactant production by a thermophilic Bacillus subtilis strain. Journal of Industrial Microbiology and Biotechnology, 18(1), 37-42.

Morikawa, M., Hirata, Y., \& Imanaka, T. (2000). A study on the structurefunction relationship of lipopeptide biosurfactants. Biochimica et Biophysica Acta (BBA)-Molecular and Cell Biology of Lipids, 1488(3), 211218.

Mulligan, C. N. (2005). Environmental applications for biosurfactants Environmental pollution, 133(2), 183198.

Rahayu, S. (2015). Pengaruh sumber karbon dan nitrogen pada produksi biosurfaktan oleh bakteri Pseudomonas aerginosa BIOPA 2411 (Doctoral dissertation, Institut Teknologi Sepuluh Nopember).

Sarafin, Y., Donio, M. B. S., Velmurugan, S., Michaelbabu, M., \& Citarasu, T. (2014). Kocuria marina BS-15 a biosurfactant producing halophilic bacteria isolated from solar salt works in India. Saudi journal of biological sciences, 21(6), 511-519.

Sharma, R., \& Gupta, A. (2014). Differentiation of oral Streptococcal species by haemolysis in blood agar medium in vitro. International Journal of Engineering and Advanced Technology, 4, 143-144.

Suganthi, C., Mageswari, A., Karthikeyan, S., Anbalagan, M., Sivakumar, A., \& Gothandam, K. M. (2013). Screening and optimization of protease 
production from a halotolerant Bacillus licheniformis isolated from saltern sediments. Journal of Genetic Engineering and Biotechnology, 11(1), 47-52.

Ventosa, A., Nieto, J. J., \& Oren, A. (1998). Biology of moderately halophilic aerobic bacteria. Microbiol. Mol. Biol. Rev., 62(2), 504-544 
